\title{
STRATEGI PENCEGAHAN PRESSURE INJURIES (PI) BERDASARKAN EVIDENCE-BASED PRACTICE (EBP): A SYSTEMATIC REVIEW
}

\author{
Wahyu Hidayat \\ STIKES Mega Buana Palopo \\ Wahyu.aries91@gmail.com
}

\begin{abstract}
The high prevalence of the incidence of Pressure Injuries (PI) in hospitals has resulted in a culture of patient safety in improving the quality of nursing services. There have been many research publications that provide options for managing and preventing pressure sores. However, only some nurses apply evidence-based practice in health services in hospitals. The aims of this study was to determine PI prevention strategies based on Evidence-Based Practice (EBP). This type of research is systematic review research with literature search sources conducted on four indexed journal portals, namely PubMed, Wiley, ProQuest, and Google Scholar. The results of this study indicate that 3427 research articles were identified, then screened by the exclusion of articles that were double publications and not the last 10 years. Furthermore, excluding articles that are not research journals, is not free full text, and does not fit into the variable, leaving 11 articles included. It can be concluded that PI prevention can be improved by maximizing nursing care based on EBP. The results of the study provide intervention options that are integrated into the delivery of nursing services to improve the quality of care. PI prevention cannot be carried out by implementing only one preventive intervention. Maximizing all existing interventions can reduce the incidence of PI. It is expected that nurses will continue to improve their abilities and skills in searching and finding research results that can be used in PI prevention. Interventions based on EBP are an innovation that needs to be improved for all nurses.
\end{abstract}

\section{Keywords :Nurse, Pressure Injuries, Evidence-Based Practice}

\section{PENDAHULUAN}

Pressure Injuries (PI) adalah kerusakan jaringan lokal pada kulit atau jaringan dibawahnya akibat penonjolan tulang sebagai hasil dari tekanan atau tekanan yang bersamaan dengan adanya geseran (NPUAP, EPUAP, \& PPPIA, 2014). PI dapat dipengaruhi oleh beberapa faktor seperti perfusi yang buruk, nutrisi, diabetes, kelembaban kulit, albumin yang rendah dan status kulit itu sendiri atau braden score (Børsting et al., 2018; Coleman et al., 2014).

Beberapa penelitian di dunia yang menunjukkan masih tingginya angka kejadian dekubitus. Prevalensi kejadian dekubitus diseluruh dunia dari tahun $2000-$ desember 2015 berkisar antara 6\% - 18,5\% (Tubaishat, Papanikolaou, Anthony, \&
Habiballah, 2017). Penelitian yang dilakukan di Norwegia menunjukkan prevalensi PI sebesar 14,9\% yang mana dipengaruhi oleh usia, BB rendah, penyakit diabetes, serta braden scores(Børsting et al., 2018). Sedangkan prevalensi kejadian PI di Indonesia sebesar 4,5\% (Amir, Lohrmann, Halfens, \& SChols, 2017). Tingginya angka dekubitus diakibatkan laporan yang tidak lengkap, sebagaimana hasil penelitian menunjukkan sebesar 69,7\% laporan insiden cedera tekanan namun tidak dilaporkan secara akurat (Barakat-Johnson et al., 2018).

PI sering terjadi pada titik-titik tekanan umum pada tonjolan tulang seperti sakrum, bokong, tumit, bagian belakang kepala, siku, bahu, pinggul, tuberositas iskia, sisi lutut dan pergelangan kaki / malleoli (Hommel \& 
Santy-tomlinson, 2018). Kejadian PI kebanyakan ditemui pada pasien di rumah sakit dan di lingkungan masyarakat, paling sering pada lansia dan tidak bergerak (pasien ortopedi), mereka yang menderita penyakit akut parah (pasien di unit perawatan intensif) dan pada orang dengan defisit neurologis (dengan cedera saraf tulang belakang) (McInnes, Cullum, Bell-Syer, Dumville, \& Jammali-Blasi, 2010)

Terjadinya PI pada pasien yang dirawat dirumah sakit dapat memberikan dampak buruk pada pasien.PI mengakibatkan rasa sakit dan kesulitan jangka pendek dan jangka panjang bagi pasien dan sering dianggap sebagai indikator kualitas perawatan yang tidak memadai, yang mengarah ke litigasi(Hommel \& Santy-tomlinson, 2018).Timbulnya komplikasi nyeri dan infeksi yang mengikuti PI dapat menambah panjang lama perawatan, bahkan adanya luka tekan menjadi penanda buruk prognosis secara keseluruhan dan mungkin berkontribusi terhadap mortalitas pasien.Selain itu, PI juga memperpanjang hari rawat dan meningkatkan biaya perawatan. Rata-rata biaya perawatanPI sebesar $€ 2.34$ - $€ 77.36$ per pasien per rawat inap. Angka ini jauh lebih tinggi jika dibandingkan dengan biaya pencegahan PI sebesar $€ 7.87$ per pasien per rawat inap (Demarre, Verhaeghe, Annemans, \& Hecke, 2015).

Tekanan merupakan faktor utama terbentuknya PI.Secara sederhana, ketika bagian tubuh terpapar tekanan terutama bagian tubuh dengan tulang yang menonjol, akan menyebabkan kompresi jaringan di bawah kulit. Kompresi ini akan menimbulkan gangguan pada suplai darah lokal dan akhirnya terjadi kerusakan jaringan akibat tekanan (Dealey et al., 2013).Bagian penting dari proses peningkatan layanan untuk mengurangi insiden cedera tekanan adalah untuk memastikan bahwa praktisi berpendidikan baik dan memiliki keterampilan dan pengetahuan praktik berbasis bukti dalam pencegahan cedera tekanan (Hommel \& Santy-tomlinson, 2018). Selain itu, telah direkomendasikan dengan tetap menggunakan praktik berbasis bukti dalam pencegahan PI untuk menghilangkan kesenjangan yang ada (Jankowski \& Nadzam, 2011).

Beberapa penelitian tentang EvidenceBased Practice(EBP) menunjukkan bahwa praktik berbasis bukti mampu meningkatkan kualitas pelayanan diberbagai tingkat layanan kesehatan yang ada.Reposisi pasien dengan risiko tekanan ulkus setiap tiga jam pada malam hari, menggunakan kemiringan $30^{\circ}$, mengurangi kejadian ulkus tekanan dibandingkan dengan perawatan biasa(Moore, Cowman, \& Conroy, 2011). Penggunaan Sensor pasien pada perawatan pasien di unit perawatan intensif menunjukkan 1,6\% lebih efektif mencegah kejadian PI dibanding dengan pasien yang tidak menggunakan sensor pasien(Pickham et al., 2018). Penerapan pencegahan PI berbasis bukti mampu menurunkan kejadian dekubitus 12,5\% - 3,2\% (Linda, 2011). Penelitian lain menyebutkan penurunan PI dari 34,3\% menjadi 7,53\% (Martin et al., 2017). Hal ini menunjukkan bahwa penerapan EBP yang baik mampu meningkatkan kualitas pelayanan yang diberikan kepada pasien dan keluarga.

Untuk meningkatkan penerapan EBP, maka diperlukan suatu strategi yang tepat untuk memaksimalkan pencegahan PI.Salah satu strategi pencegahan luka yang dapat dilakukan adalah SSKIN yang memfokuskan upaya pencegahan pada lima komponen dasar yaitu surface, skin, keep moving, inkontenensia, dan nutrition(Healthcare Improvement Scotland, 2009). Semua elemen dalam bundel didasarkan pada bukti kuat (Stephen-haynes, 2013).Bundel perawatan SSKIN sangat penting dalam pencegahan PI dan harus diterapkan untuk setiap pasien yang berisiko (Stephen-haynes, 2013). Sehingga dengan penerapan intervensi pencegahan, diharapkan mampu menghilangkan kejadian PI.

Meskipun demikian, perawat lebih menerapkan apa yang mereka pelajari saat di pendidikan dalam pemberian pelayanan keperawatan kepada pasien. Pelayanan keperawatan yang diterapkan oleh perawat bukan pada EBP tetapi lebih memilih untuk diberitahu oleh rekan kerja(Pravikoff, 
Tanner, \& Pierce, 2005), pengalaman pribadi(Egerod \& Hansen, 2005), dan hanya berdasar kebijakan rumah sakit, bukan dari laporan penelitian(Gerrish \& Clayton, 2004), sehingga hasil-hasil publikasi tidak digunakan secara optimal oleh perawat dalam mencegah terjadinya PI di rumah sakit.

Masih tingginya prevalensi kejadian PI di rumah sakit mengakibatkan budaya keselamatan pasien dalam meningkatkan kualitas pelayanan keperawatan belum optimal.Telah banyak publikasi penelitian yang memberikan pilihan dalam menangani dan mencegah PI. Namun hanya sebagian perawat saja yang menerapkan praktik berbasis bukti dalam layanan kesehatan di rumah sakit. Perawat yang melakukan asuhan keperawatan hanya berdasar pada apa yang mereka pelajari saat masih menempuh pendidikan keperawatan. Padahal dalam melakukan asuhan keperawatan professional dibutuhkan suatu inovasi untuk memberikan pelayanan yang efesien dan efektif dalam mengatasi permasalahan pasien.Hal inilah yang menimbulkan pertanyaan bagaimanakah evaluasi dari penerapan evidence-based nursing dalam mencegah pressure ulcer di pelayanan rumah sakit.

\section{METODE}

Algoritma pencarian literature menggunakan pendekatan $\mathrm{PICO}(\mathrm{T})$ dengan kata kunci Nurse Associate OR Nurse Practitioner OR Clinical Nurses OR Register Nurses OR Front Line Nurses AND Evidence Based Practice OR EBP OR Evidence Based Nursing OR EBN OR Evidence Based Nursing Practice OR EBNP AND Decubitus OR Decubitus Ulcer OR Pressure Ulcer OR Pressure Injuries OR Pressure Injury OR Pressure Sore OR Bed Sores OR Bed Sore OR Bedsore. Sumber pencarian literature dilakukan pada empat portal jurnal terindeks yaitu PubMed, Wiley, ProQuest, dan Google Schoolar.Selain itu, untuk pencarian sekunder juga dilakukan untuk melengkapi literatur yang ada.

\section{HASIL}

Berdasarkan hasil pencarian tersebut, didapatkan artikel yang teridentifikasi sebanyak 3427 penelitian, kemudian dilakukan screening dengan mengekslusi 1977 artikel yang double publikasi dan bukan 10 tahun terakhir. Selanjutnya, mengeklusi artikel yang bukan jurnal penelitian sebanyak 362 , tidak free full text sebanyak 812, dan tidak sesuai dengan variabel sebanyak 85 , sehingga menyisakan 11 artikel yang diinklusi (Tabel 1).

\section{PEMBAHASAN \\ Penilaian Risiko}

Penilaian risiko dianjurkan sebagai langkah pertama dalam pencegahan PI dalam asuhan keperawatan. Pencegahan PI berbasis bukti mencakup penilaian risiko dan harus ditindaklanjuti dengan rencana perawatan yang mencakup tujuan dan evaluasi (Sving, Fredriksson, Gunningberg, \& Mamhidir, 2017). Penilaian harus segera dilakukan saat pasien masuk (Bergstrom, Braden, Kemp, Champagne, \& Ruby, 1998; Kumar \& Mahal, 2017) dan ditinjau kembali setiap kali kondisi pasien berubah secara signifikan (Kumar \& Mahal, 2017). Penilaian kulit harus dilakukan maksimal 8 jam setelah pasien masuk (Hommel \& Santy-tomlinson, 2018; Rodrigues et al., 2016). Penilaian berkelanjutan meningkatkan prediksi dan memungkinkan penyempurnaan protokol pencegahan berbasis risiko (Bergstrom et al., 1998). Penilaian risiko yang dilakukan harus dilakukan secara berkesinambungan menggunakan alat ukur agar dapat diberikan pencegahan sedini mungkin.

Penggunaan alat ukur dalam menilai risiko PI hendaknya menggunakan alat ukur yang direkomendasikan.Braden scale direkomendasikan sebagai alat ukur yang memiliki sensitivitas dan kapasitas prediksi yang baik untuk menilai risiko PI (Pancorbo-hidalgo, Garcia-fernandez, Lopez-Medina, \& Alvarez-nieto, 2006). Skala penilaian risiko akan membantu perawat untuk membuat penilaian sistematis terhadap kondisi pasien dan risiko perkembangan PI(Kumar \& Mahal, 2017). Penggunaan alat ukur yang telah dipahami 
oleh perawat, akan membuat proses penilaian risiko dapat berjalan dengan lancar.

Penilaian risiko terjadinya PI harus segera dilakukan terhadap pasien-pasien yang beresiko untuk mengalami PI. Alat penilaian risiko akan memungkinkan untuk mengidentifikasi pasien yang benar-benar membutuhkan tindakan pencegahan segera dan yang akan mengalami luka tekan jika pencegahan ditunda (Kumar \& Mahal, 2017). Para peneliti berpendapat bahwa di rumah sakit, di mana sebagian besar pasien tidak sadar dan terbaring di tempat tidur, mereka paling rentan untuk mendapatkan PI(Kumar \& Mahal, 2017). Dalam perawatan tersier, prediksi yang paling akurat terjadi pada 48 hingga 72 jam setelah masuk dan saat ini rencana perawatan dapat disempurnakan (Bergstrom et al., 1998). Dengan melakukan penilaian sedini mungkin, maka memungkinkan perawat untuk memberikan tindakan pencegahan PI.

\section{EBP Pencegahan PI}

Berbagai upaya pencegahan yang dilakukan untuk mengurangi PI. Strategi pencegahan dapat dipertimbangkan dalam hal tekanan dan pengurangan geser dan berpotensi pengelolaan iklim mikro (Dealey et al., 2013). Hal ini umumnya dicapai dengan redistribusi tekanan baik dalam hal melepaskan tekanan secara manual atau melalui 'penyebaran beban' (Dealey et al., 2013). Berbagai jenis permukaan penopang telah dikembangkan dengan mekanisme yang berbeda untuk tekanan dan pengurangan geser termasuk mendistribusikan kembali berat di atas area permukaan tubuh maksimum, dan secara mekanik mengganti tekanan di bawah tubuh untuk mengurangi durasi tekanan yang diberikan (Clark, 2011).Untuk mengurangi PI, pemerataan distribusi tekanan pada permukaan penopang dapat dijadikan sebagai salah satu upaya pengurangan PI.

Beberapa hasil penelitian saat ini menunjukkan efektifitas penggunaan permukaan untuk mengurangi PI. Bukti kepastian moderat saat ini menunjukkan bahwa, dibandingkan dengan permukaan rumah sakit standar, powered active air surfaces and powered hybrid air surfaces mungkin mengurangi kejadian ulkus tekanan masing-masing sebesar 58\% dan 78\% (Shi, Dumville, \& Cullum, 2018). Namun jika ditinjau dari aspek kenyamanan, powered active air surfaces and powered hybrid air surfaces lebih rendah jika dibandingkan standard hospital surfaces (Shi et al., 2018). Penggunaan sheepskin mattress (SSM) lebih efektif meningkatkan area kontak dan menurunkan besarnya tekanan kontak jika dibandingkan dengan air mattress (Zhou, Xu, Tang, \& Chen, 2014). SSM lebih unggul dalam mendistribusikan dan menghilangkan tekanan sehingga dapat digunakan dalam perawatan klinis (Zhou et al., 2014). Pemilihan permukaan penopang yang tepat tentu disesuaikan dengan kemampuan rumah sakit untuk menyediakan fasilitas yang mampu menurunkan PI. Biaya rata-rata yang dikeluarkan rumah sakit terkait pencegahan PI lebih rendah jika dibandingkan dengan biaya rata-rata perawatan PI(Demarre et al., 2015).

Selain upaya, penyediaan support surface yang tepat, upaya pencegahan yang dapat dilakukan adalah dengan memaksimalkan peran perawat perawat dalam mengurangi PI melalui pengaturan posisi pasien. Secara tradisional, pengurangan tekanan telah dicapai dengan reposisi pasien secara teratur, baik oleh pasien sendiri atau dengan bantuan dari staf perawat (Dealey et al., 2013). Telah direkomendasikan untuk melakukan reposisi setiap 6 jam dan 4 jam bagi pasien dengan risiko tinggi (NICE, 2014). Hasil penelitian lain menujukkan reposisi pada pasien dengan risiko tinggi PI setiap 3 jam pada malam hari dengan kemiringan 30, mengurangi PI jika dibandingkan dengan perawatan biasa (Moore et al., 2011). Namun, frekuensi dapat disesuaikan dengan kebutuhan individu, berdasarkan pemantauan kulit dengan hati-hati untuk ada atau tidak adanya eritema persisten atas penonjolan tulang (Dealey et al., 2013).

Upaya pencegahan PI, dapat dimaksimalkan dengan mengkombinasikan 
reposisi dengan penggunaan balutan pada pasien yang beresiko. Bukti efektivitas balutan dengan menggunakan Mepilex mampu mencegah terjadiya PI pada sacrum dan tumit pada pasien dengan risiko tinggi (Black et al., 2014) Balutan ini dapat memaksimalkan efek perlindungan dan meminimalisir adanya geseran dan tekanan yang dialami pasien selama proses perawatan (Black et al., 2014). Penggunaan balutan Mölnlycke Mepilex Border Sacrum dan Mepilex Heel mampu mengurangi risiko sebanyak $80 \%$ kejadian PI pada pasien yang dirawat difasilitas kesehatan panti jompo (Santamaria, Gerdtz, Kapp, Wilson, \& Gefen, 2018).

\section{Strategi Pencegahan PI}

Pencegahan PI harus dilakukan dengan memaksimalkan upaya pencegahan terhadap semua aspek yang dapat menyebabkan terjadinya luka tekan. SSKIN merupakan strategi pencegahan PI dengan memfokuskan upaya pencegahan pada lima kompenen dasar (Healthcare Improvement Scotland, 2009). Tujuan bundel adalah untuk mengikat praktik terbaik bersama-sama dengan cara yang dapat diandalkan untuk mengurangi terjadinya PI(Stephen-haynes, 2013). Menghilangkan salah satu intervensi dalam bundel SSKIN kemungkinan akan menghasilkan pengembangan PI (Stephen-haynes, 2013). Bundel perawatan SSKIN sangat penting dalam pencegahan PI dan harus diterapkan untuk setiap pasien yang berisiko (Stephenhaynes, 2013).

\section{Surface}

Permukaan penopang pada tempat tidur dan kursi harus memenuhi kebutuhan masing-masing pasien (Hommel \& Santytomlinson,2018).Peralatan/permukaan

pendukung untuk mengurangi tekanan dan mencegah kerusakan kulit harus digunakan dan dievaluasi secara teratur untuk meninjau efektivitasnya (Mitchell, 2018). Setelah pasien dapat duduk di tempat tidur, risiko cedera tekanan masih perlu diketahui sampai pasien sepenuhnya dapat bergerak (Hommel \& Santy-tomlinson, 2018).

\section{Skin}

Penilaian kulit sangat penting untuk mencegah kerusakan kulit, mengelola PI yang ada atau mencegah kerusakan lebih lanjut, dan kerapuhan kulit harus diidentifikasi pada setiap penilaian risiko (Mitchell, 2018). Indikasi perubahan kulit seperti eritema blanching dan non-blanching harus dicatat.Eritema non-blanching merupakan indikasi kerusakan tekanan dan harus segera ditindaklanjuti. Tindakan pencegahan harus segera dimulai dan pasien harus dinilai ulang setidaknya setiap 2 jam sampai ini diselesaikan (NICE, 2014). Fokus pencegahan PI diarahkan pada upaya perawat dalam menilai status kesehatan pasien, menilai daerah tekanan, lipatan kulit bariatric, derajat ulkus dan kesesuaian laporan. Mengajarkan pasien dan perawat untuk memeriksa kulit, mengidentifikasi tekanan, geser atau gesekan dan memberikan leaflet (Jones, 2013). Identifikasi faktor risiko untuk pengembangan PI sangat penting untuk pencegahan yang efektif dan efesien (Beeckman, Lancker, Hecke, \& Verhaeghe, 2014).

Geser dan gesekan merupakan faktor utama dalam pengembangan PI. Gesekan menyebabkan abrasi pada epidermis dan dermis, meningkatkan kerentanan terhadap kerusakan akibat tekanan yang dapat membahayakan pasien yang memerlukan reposisi karena lapisan kulit bergeser satu sama lain ketika pasien naik ke tempat tidur (Hanson et al, 2010). Baik geser maupun gesekan, gabungan atau secara terpisah, dapat memiliki konsekuensi negatif.Ini harus dipertimbangkan ketika menilai kulit dan tindakan harus diambil untuk meminimalkan faktor risiko bila memungkinkan. Krim dan film dapat membantu mengurangi gesekan (Mitchell, 2018).

\section{Keep Moving}

Beberapa hal yang perlu diperhatikan dalam hal ini antara lain; kebutuhan untuk jadwal pemosisian ulang dengan kemiringan $30^{\circ}$. Hindari gesekan, 
geser, dan muat ke perangkat atau peralatan, posisikan pasien untuk memastikan distribusi tekanan optimal dan gunakan peralatan seperti lembaran geser (Jones, 2013). Pasien yang diidentifikasi sebagai risiko pengembangan PU perlu sering melakukan reposisi (NPUAP et al., 2014).

Rekomendasi reposisi setidaknya setiap 6 jam dan setiap 4 jam bagi mereka yang berisiko tinggi dan mendorong pasien untuk melakukannya sendiri (NICE, 2014). Jika memungkinkan, pasien tidak boleh diarahkan ke area yang memerah karena kemerahan adalah indikasi bahwa tubuh belum pulih dari pemuatan tekanan sebelumnya (NPUAP et al., 2014). Pijat merupakan kontraindikasi dan tidak direkomendasikan sebagai strategi untuk pencegahan PU (NPUAP et al., 2014). Pijat menyebabkan gesekan dan geser yang dapat merusak sirkulasi mikro yang halus dan menyebabkan peradangan dan kerusakan jaringan (Hommel \& Santy-tomlinson, 2018).

Perawat harus memastikan bahwa pasien merasa nyaman dan pasien yang berisiko mengalami PI memiliki grafik reposisi di tempat tidur (NPUAP et al., 2014). Ketika mempertimbangkan peralatan, penting untuk diingat bahwa kasur busa standar tidak memadai untuk pasien dengan PI.Pasien berisiko tinggi membutuhkan kasur busa dengan spesifikasi tinggi. Namun, tidak ada bukti yang menunjukkan

meningkat ke dokter rawat inap atau dokter umum bila diperlukan (Mitchell, 2018). Hidrasi dan nutrisi sangat penting untuk perbaikan jaringan dan PImanajemen (Saghaleini et al., 2018). Penyelesaian yang benar dari panduan alat ini intervensi seperti akses ke makanan dan cairan, saran diet (bagaimana mengikuti diet seimbang dengan energi, protein dan persyaratan mikronutrien), rujukan dietitian dan intervensi lebih lanjut seperti minuman suplemen atau makan tabung (NICE, 2014).

\section{KESIMPULAN DAN SARAN}

bahwa satu kasur busa spesifikasi tinggi lebih unggul dari yang lain (NPUAP et al., 2014). Permukaan pendukung harus digunakan untuk mencegah PI tumit, seperti perangkat pelindung tumit yang mengangkat tumit sepenuhnya. Praktisi harus memastikan lutut sedikit fleksi saat perangkat ini digunakan (NPUAP et al., 2014).

\section{Inkontenensia}

Untuk pencegahan PI, status eliminasi pasien harus dinilai dan setiap masalah kontinuasi ditangani (Mitchell, 2018). Perawatan kulit secara teratur harus dilakukan untuk mengelola keringat dan membersihkan kulit kotor atau basah (Mitchell, 2018). Inkontenensia dapat menyebabkan dermatitis yang dapat menimbulkan PI(Beeckman et al., 2014). Perawat harus meminta saran dari penasihat kontinens jika sesuai (Mitchell, 2018). Setiap bentuk kelembaban ekstrinsik dapat menyebabkan kerusakan kulit yang rentan (Beeckman et al., 2014).

\section{Nutrition}

Diskusikan pengetahuan tentang diet sehat dan mempertimbangkan kebutuhan untuk fortifikasi makanan dan suplemen gizi. Memberikan selebaran saran dan mendidik pasien dan/atau perawat (Jones, 2013). Pasien berisiko harus diamati untuk tanda-tanda dehidrasi; grafik cairan dan makanan harus diatur dan kekhawatiran

\section{Kesimpulan}

Pencegahan PI dpat ditingkatkan dengan memaksimalkan asuhan kkeperawatan berdasarkan EBP. Hasil-hasil penelitian memberikan pilihan intervensi yang dapatkan diintegrasikan dalam pemberian pelayanan keperawatan untuk meningkatkan kualitas asuhan. Pencegahan PI Tidak dapat dilakukan hanya dengan melaksanakan satu intervensi pencegahan saja. Memaksimalkan seluruh intervensi yang ada, dapat menurunkan kejadian PI.

\section{Saran}


Diharapkan kepada perawat untuk terus meningkatkan kemampuan dan keterampilan dalam mencari dan menemukan hasil-hasil penelitian yang dapat digunakan dalam pencegahan PI.Intervensi berdasarkan EBP merupakan sebuah inovasi yang perlu ditingkatkan bagi semua perawat.

\section{DAFTAR PUSTAKA}

Amir, Y., Lohrmann, C., Halfens, R. J., \& SChols, J. M. (2017). Pressure ulcers in four Indonesian hospitals: prevalence, patient characteristics, ulcer characteristics, prevention and treatment. International Wound Journal, 14(1), 184-193. https://doi.org/10.1111/iwj.12580

Barakat-Johnson, M., Lai, M., Barnett, C., Wand, T., Lidia Wolak, D., Chan, C., ... White, K. (2018). Hospital-acquired pressure injuries: Are they accurately reported? A prospective descriptive study in a large tertiary hospital in Australia. Journal of Tissue Viability. https://doi.org/10.1016/j.jtv.2018.07.003

Beeckman, D., Lancker, V., Hecke, A. Van, \& Verhaeghe, S. (2014). A Systematic Review and Meta-Analysis of IncontinenceAssociated Dermatitis, Incontinence, and Moisture as Risk Factors for Pressure Ulcer Development. Research \& Nursing Health, 37, 204-218. https://doi.org/10.1002/nur.21593

Bergstrom, N., Braden, B., Kemp, M., Champagne, M., \& Ruby, E. (1998). Predicting Pressure Ulcer Risk: A Multisite Study of the Predictive Validity of the Braden Scale. Nursing Research, 47(5), 261-269.

Black, J., Clark, M., Dealey, C., Brindle, C. T., Alves, P., Santamaria, N., \& Call, E. (2014). Dressings as an adjunct to pressure ulcer prevention: consensus panel recommendations. International Wound Journal, $\quad$ 484-488. https://doi.org/10.1111/iwj.12197

Børsting, T. E., Tvedt, C. R., Skogestad, I. J., Granheim, T. I., Gay, C. L., \& Lerdal, A. (2018). Prevalence of Pressure Ulcer and Associated Risk Factors in Middle and
Older Age Medical Inpatient in Norway. Journal Of Clinical Nursing, 27(32), e535e543.

https://doi.org/https://doi.org/10.1111/jocn. 14088

Chiari, P., Forni, C., Guberti, M., Gazineo, D., Ronzoni, S., \& Alessandro, F. D. (2017). Predictive Factors for Pressure Ulcers in an Older Adult Population Hospitalized for Hip Fractures: A Prognostic Cohort Study. PLoS ONE, 12(1), 1-13. https://doi.org/10.1371/journal.pone.016990 9

Coleman, S., Nixon, J., Keen, J., Wilson, L., Mcginnis, E., Dealey, C., ... Nelson, E. A. (2014). A New Pressure Ulcer Conceptual Framework. 70(20), 2222-2234. https://doi.org/10.1111/jan.12405

Dealey, C., Brindle, C. T., Black, J., Alves, P., Santamaria, N., \& Call, E. (2013). Challenges in pressure ulcer prevention. 309-312. https://doi.org/10.1111/iwj.12107

Demarre, L., Verhaeghe, S., Annemans, L., \& Hecke, A. Van. (2015). International Journal of Nursing Studies The cost of pressure ulcer prevention and treatment in hospitals and nursing homes in Flanders : A cost-of-illness study. International Journal of Nursing Studies. https://doi.org/10.1016/j.ijnurstu.2015.03.00 5

Egerod, I., \& Hansen, G. M. (2005). Evidencebased practice among danish cardiac nurses: A national survey. Journal of Advanced Nursing, 51(5), 465-473. https://doi.org/10.1111/j.13652648.2005.03525.x

Flodgren, G., Rojas-reyes, M. X., Cole, N., \& Foxcroft, D. R. (2014). Effectiveness of organisational infrastructures to promote evidence-based nursing practice. https://doi.org/10.1002/14651858.CD00221 2.pub2.Effectiveness

Gerrish, K., \& Clayton, J. (2004). Promoting evidence-based practice: An organizational approach. Journal of Nursing Management, 12(2), 114-123.

Gillespie, B. M., Chaboyer, W., Sykes, M., O'Brien, J., \& Brandis, S. (2014). Development and Pilot Testing of a PatientParticipatory Pressure Ulcer Prevention. 
Journal Nursing Care Quality, 29(1), 7482.

https://doi.org/10.1097/NCQ.0b013e3182a7 $1 \mathrm{~d} 43$

Healthcare Improvement Scotland. (2009). Prevention and Management of Pressure Ulcers. Retrieved from http

Hommel, A., \& Santy-tomlinson, J. (2018). Pressure Injury Prevention and Wound Management. In Fragility Fracture Nursing, Perspectives in Nursing Manegement and Care for Older Adults (pp. 85-94). https://doi.org/10.1007/978-3319-76681-2

Jankowski, I. M., \& Nadzam, D. M. (2011). Identifying Gaps, Barriers, and Solutions in Implementing Pressure Ulcer Prevention Programs. Joint Commission Journal on Quality and Patient Safety, 37(6), 253-264. https://doi.org/10.1016/S1553-

7250(11)37033-X

Jones, D. (2013). Pressure ulcer prevention in the community setting. Nursing Standard, $28(3)$, 47-55. https://doi.org/10.7748/ns2013.09.28.3.47.e 7660

Kumar, A., \& Mahal, R. (2017). Modified Delphi Technique : Content validity of the Pressure ulcer risk assessment tool. Journal of Nursing Science and Practice, 7(3), 17-19. Retrieved from https://www.researchgate.net/profile/Ashok _Kumar490/publication/322791657_Modifi ed_Delphi_Technique_Content_validity_of the_Pressure_ulcer_risk_assessment_tool/1 inks/5a7050d60f7e9ba2e1c9d112/Modified -Delphi-Technique-Content-validity-of-thePressure-ulcer

Linda, G. (2011). Evaluating Evidence-Based Intervention to Prevent Fall and Pressure Ulcers. Retrieved from https://apps.dtic.mil/dtic/tr/fulltext/u2/a6186 79.pdf

Martin, D., Albensi, L., Haute, S. Van, Froese, M., Montgomery, M., Lam, M., ... Basova, N. (2017). Healthy Skin Wins: A Glowing Pressure Ulcer Prevention Program That Can Guide Evidence-Based Practice. Worldviews on Evidence-Based Nursing, 14(6), 473-483. https://doi.org/10.1111/wvn.12242
McInnes, E., Cullum, N. A., Bell-Syer, S. E., Dumville, J. C., \& Jammali-Blasi, A. (2010). Support surfaces for pressure ulcer prevention (Review). Cochrane Database of Systematic Reviews, 2010(5). https://doi.org/10.1002/14651858.CD00173 5.pub3

Mitchell, A. (2018). Adult pressure ulcer area care: preventing pressure ulcers. British Journal Of Nursing, 27(18r), 1050-1052. https://doi.org/10.12968/bjon.2018.27.18.10 50

Moore, Z., Cowman, S., \& Conroy, M. (2011). A randomised controlled clinical trial of repositioning, using the $30^{\circ}$ tilt , for the prevention of pressure ulcers. Journal of Clinical Nursing, 20, 2633-2644. https://doi.org/10.1111/j.13652702.2011.03736.x

NICE. (2014). Pressure ulcers: prevention and management. Retrieved from https://www.nice.org.uk/guidance/cg179

NPUAP, EPUAP, \& PPPIA. (2014). Prevention and Treatment of Pressure Ulcers: Quick Reference Guide. Retrieved from http://tinyurl.com/yck2mmr6

Pancorbo-hidalgo, P. L., Garcia-fernandez, F. P., Lopez-Medina, I. M., \& Alvarez-nieto, C. (2006). Risk assessment scales for pressure ulcer prevention: a systematic review. Journal of Advanced Nursing, 54(1), 94$110 . \quad$ https://doi.org/10.1111/j.13652648.2006.03794.x

Pickham, D., Berte, N., Pihulic, M., Valdez, A., Mayer, B., \& Desai, M. (2018). Effect of a wearable patient sensor on care delivery for preventing pressure injuries in acutely ill adults: A pragmatic randomized clinical trial ( LS-HAPI study ). International Journal of Nursing Studies, 80(June 2017), 12-19. https://doi.org/10.1016/j.ijnurstu.2017.12.01 2

Pravikoff, D. S., Tanner, A. B., \& Pierce, S. T. (2005). Readiness of U.S. Nurses for Evidence-Based Practice. The American Journal of Nursing, 105(9), 40-51.

Rodrigues, G. C. A., Vasconcelos, J. de M. B., Melo, F. M. de A. B., Vigolvino, L. P., Sousa, A. T. O. de, Santos, I. B. da C. S., ... Martins, N. E. (2016). Knowledge and 
Opinions of Nursing Professionals about Pressure Ulcers Prevention. International Medical Society, 9(101), 1-13. https://doi.org/10.3823/1972

Saghaleini, S. H., Dehghan, K., Shadvar, K., Sanaie, S., Mahmodpoor, A., \& Ostadi, Z. (2018). Pressure Ulcer and Nutrition. Indian Journal of Critical Care Medicine, 22(4), 283-289.

https://doi.org/10.4103/ijccm.IJCCM_277_ 17

Santamaria, N., Gerdtz, M., Kapp, S., Wilson, L., \& Gefen, A. (2018). A randomised controlled trial of the clinical effectiveness of multi-layer silicone foam dressings for the prevention of pressure injuries in highrisk aged care residents: The Border III Trial. International Wound Journal, 1-9. https://doi.org/10.1111/iwj.12891

Shi, C., Dumville, J. C., \& Cullum, N. (2018). Support surfaces for pressure ulcer prevention: A network meta-analysis. PLoS ONE, 13(2), 1-29. https://doi.org/10.1371/journal.pone.019270 7

Stephen-haynes, J. (2013). The Role of Barrier Protection in Pressure Ulcer Prevention. British Journal Of Nursing, 22(20), 52-58. https://doi.org/10.12968/bjon.2013.22.Sup2 $0 . \mathrm{S} 52$

Sving, E., Fredriksson, L., Gunningberg, L., \& Mamhidir, A. G. (2017). Getting evidencebased pressure ulcer prevention into practice: a process evaluation of a multifaceted intervention in a hospital setting. Journal of Clinical Nursing, 26(1920), https://doi.org/10.1111/jocn.13668

Thomas, A., \& Thomas, A. (2012). Assessment of nursing knowledge and wound documentation following a pressure ulcer educational program in a long-term care facility: a capstone project. Wound Practice Nd Research, 20(3).

Tubaishat, A., Papanikolaou, P., Anthony, D., \& Habiballah, L. (2017). Pressure Ulcers Prevalence in the Acute Care Setting: A Systematic Review , 2000-2015. Clinical Nursing Research, 1-28. https://doi.org/10.1177/1054773817705541

Zhou, J., Xu, B., Tang, Q., \& Chen, W. (2014).
Application of the sheepskin mattress in clinical care for pressure relieving: a quantitative experimental evaluation. Apllied Nursing Research, 27, 47-52. https://doi.org/10.1016/j.apnr.2013.10.008 
Tabel 1 Sintesis grid

\begin{tabular}{|c|c|c|c|c|c|c|}
\hline No & Authors & Judul & Tujuan & Design & Instrumen & Output \\
\hline 1 & $\begin{array}{l}\text { (Flodgren, } \\
\text { Rojas-reyes, } \\
\text { Cole, \& } \\
\text { Foxcroft, 2014) }\end{array}$ & $\begin{array}{l}\text { Effectiveness of } \\
\text { organisational } \\
\text { infrastructures to } \\
\text { promote } \\
\text { evidence-based nursing } \\
\text { practice }\end{array}$ & $\begin{array}{l}\text { Untuk menilai } \\
\text { efektivitas } \\
\text { infrastruktur } \\
\text { organisasi dalam } \\
\text { mempromosikan } \\
\text { evidence sbased } \\
\text { nursing practice. }\end{array}$ & $\begin{array}{l}\text { Randomised } \\
\text { controlled trials, } \\
\text { controlled clinical } \\
\text { trials, interrupted } \\
\text { times series (ITSS) }\end{array}$ & $\begin{array}{l}\text { Independently } \\
\text { extracted data and } \\
\text { assessed risk of } \\
\text { bias. }\end{array}$ & $\begin{array}{l}\text { Perawat memberikan } \\
\text { pencegahan ulkus tanpa menungan } \\
\text { instruksi dokter. Tidak ada bukti } \\
\text { intervensi dalam } 3 \text { bulan penerapan } \\
\text { prosedur praktik berbasis bukti pada } \\
\text { pasien HAPUs. }\end{array}$ \\
\hline 2 & $\begin{array}{l}\text { (Thomas \& } \\
\text { Thomas, 2012) }\end{array}$ & $\begin{array}{l}\text { Assessment of nursing } \\
\text { knowledge and wound } \\
\text { documentation following } \\
\text { a pressure ulcer } \\
\text { educational program in a } \\
\text { long-term care facility: a } \\
\text { capstone project }\end{array}$ & $\begin{array}{lr}\text { Untuk menilai } \\
\text { pengetahuan } \\
\text { keperawatan dan } \\
\text { dokumentasi luka } \\
\text { berkualitas } \\
\text { mengikuti program } \\
\text { pendidikan evidence- } \\
\text { based pressure ulcer } \\
\text { (EduP) di fasilitas } \\
\text { perawatan jangka } \\
\text { panjang }\end{array}$ & $\begin{array}{l}\text { Pre-tes and post-test } \\
\text { design }\end{array}$ & 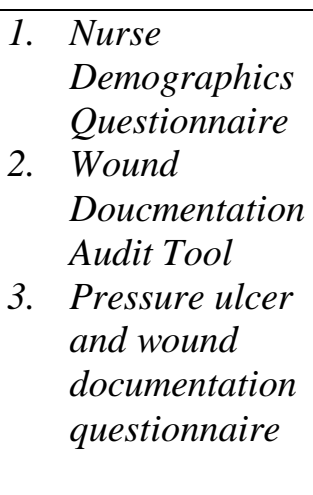 & $\begin{array}{l}\text { Ulkus tekanan EduP terbukti } \\
\text { meningkatkan pengetahuan keperawatan } \\
\text { dan meningkatkan dokumentasi luka } \\
\text { yang komprehensif dari ulkus tekanan } \\
\text { di fasilitas perawatan jangka panjang. } \\
\text { Karakteristik ulkus tekanan yang } \\
\text { terdokumentasikan untuk elemen size } \\
(59,5 \% \text { menjadi } 82,7 \%) \text {, exudate } \\
(43,9 \% \text { hingga } 70,5 \%) \text { dan tissue type } \\
(42,7 \% \text { menjadi } 63,1 \%) \text {. }\end{array}$ \\
\hline 3 & $\begin{array}{l}\text { (Rodrigues et } \\
\text { al., 2016) }\end{array}$ & $\begin{array}{l}\text { Knowledge and Opinions } \\
\text { of Nursing Professionals } \\
\text { about Pressure Ulcers } \\
\text { Prevention }\end{array}$ & $\begin{array}{l}\text { Menggambarkan } \\
\text { pengetahuan } \\
\text { profesional } \\
\text { keperawatan tentang } \\
\text { pencegahan tekanan } \\
\text { ulkus } \\
\text { menganalisis dan } \\
\text { pendapat mereka } \\
\text { pada hal yang sama. }\end{array}$ & $\begin{array}{l}\text { Exploratory, } \\
\text { descriptive and } \\
\text { quantitative study }\end{array}$ & $\begin{array}{l}\text { The Pieper } \\
\text { knowledge test }\end{array}$ & $\begin{array}{l}\text { Hasil tes menunjukkan pengetahuan } \\
\text { perawat }(75,60 \%) \text { dan asisten/teknisi } \\
(76,29 \%) \text { yang berarti para professional } \\
\text { menyadari pentingnya mencegah cedera } \\
\text { namun masih mengalami kesulitan } \\
\text { dalam pelaksanaannya. }\end{array}$ \\
\hline 4 & $\begin{array}{l}\text { Flemming, E., } \\
\text { Moore, Z., \& } \\
\text { Condel, S. } \\
(2017)\end{array}$ & $\begin{array}{l}\text { Patient and family/carer } \\
\text { experience of their } \\
\text { involvement in a regional } \\
\text { quality improvement } \\
\text { collaborative utilizing the } \\
\text { SSKIN care bundle }\end{array}$ & $\begin{array}{l}\text { untuk } \\
\text { mengeksplorasi } \\
\text { pengalaman pasien } \\
\text { dan keluarga / } \\
\text { pengasuh dalam } \\
\text { menerapkan bundel }\end{array}$ & $\begin{array}{l}\text { A qualitative } \\
\text { descriptive approachs }\end{array}$ & $\begin{array}{l}\text { One to one } \\
\text { interviews with } \\
\text { patient and focus } \\
\text { interview with } \\
\text { family- }\end{array}$ & $\begin{array}{l}\text { Baik pasien dan keluarga / pengasuh } \\
\text { memiliki keterlibatan terbatas dalam } \\
\text { pencegahan PU dalam kolaborasi. } \\
\text { Selanjutnya, kurangnya kesadaran } \\
\text { umum dari bundel perawatan SSKIN } \\
\text { diidentifikasi dengan beberapa }\end{array}$ \\
\hline
\end{tabular}




\begin{tabular}{|c|c|c|c|c|c|c|}
\hline & & & \begin{tabular}{lr} 
perawatan & \\
pencegahan & PU \\
(dikenal & sebagai \\
SSKIN) & dalam \\
kolaborasi & \\
peningkatan & kualitas \\
regional r yang \\
berjudul "Pressure \\
\multicolumn{2}{l}{ Ulcer to Zero" } \\
\end{tabular} & & & kebingungan seputar akronimnya. \\
\hline 5 & $\begin{array}{l}\text { (Martin et al., } \\
\text { 2017) }\end{array}$ & $\begin{array}{l}\text { Healthy Skin Wins: A } \\
\text { Glowing Pressure } \\
\text { Ulcer Prevention } \\
\text { Program That Can Guide } \\
\text { Evidence-Based Practice }\end{array}$ & $\begin{array}{l}\text { Untuk menentukan } \\
\text { efektivitas PUPP } \\
\text { dalam mengurangi } \\
\text { prevalensi PU, untuk } \\
\text { menentukan } \\
\text { keefektifan tutorial } \\
\text { online dalam } \\
\text { meningkatkan } \\
\text { tingkat pengetahuan } \\
\text { staf rumah sakit } \\
\text { tentang pencegahan } \\
\text { PU, dan untuk } \\
\text { mengeksplorasi } \\
\text { perspektif staf garis } \\
\text { depan dari PUPP }\end{array}$ & $\begin{array}{l}\text { A mixed methods } \\
\text { study (observational } \\
\text { survey, a pre-test } \\
\text { post-test design, and } \\
\text { qualitative nterviews) }\end{array}$ & $\begin{array}{l}\text { PU prevention form } \\
\text { and The Braden } \\
\text { Scale }\end{array}$ & $\begin{array}{l}\text { Menggabungkan pencegahan PU } \\
\text { berbasis bukti ke dalam praktik klinis } \\
\text { sangat mengurangi prevalensi PUs di } \\
\text { antara pasien rawat inap di rumah } \\
\text { sakit.Perbandingan survei observasi } \\
\text { awal dan berulang mengidentifikasi } \\
\text { penurunan prevalensi PU menjadi } \\
\text { 7,53\%. Tutorial online meningkatkan } \\
\text { pengetahuan dengan skor post-test rata- } \\
\text { rata yang signifikan. Staf garis depan } \\
\text { berjumlah tiga puluh berbagi perspektif } \\
\text { mereka tentang PUPP dengan "itu pasti } \\
\text { kombinasi dari semuanya" dan "ada } \\
\text { keterputusan antara apa yang } \\
\text { dibutuhkan dan apa yang tersedia" } \\
\text { sebagai tema utama. }\end{array}$ \\
\hline 6 & $\begin{array}{l}\text { (Coleman et al., } \\
\text { 2014) }\end{array}$ & $\begin{array}{l}\text { A new pressure ulcer } \\
\text { conceptual framework }\end{array}$ & $\begin{array}{l}\text { Untuk membahas } \\
\text { determinan penting } \\
\text { dari perkembangan } \\
\text { ulkus tekanan } \\
\text { dan mengusulkan } \\
\text { kerangka konseptual } \\
\text { ulkus tekanan baru. }\end{array}$ & DiscussionPaper & & 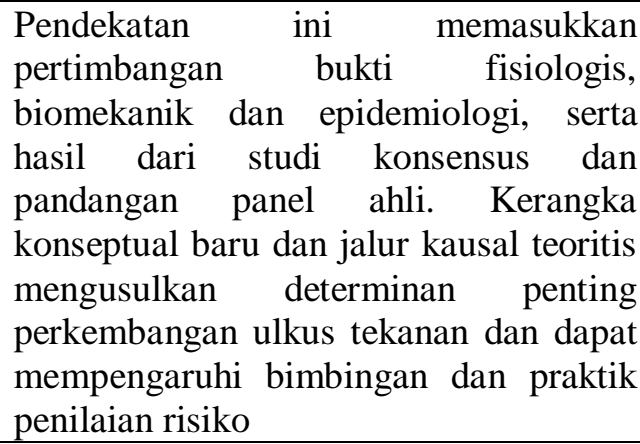 \\
\hline 7 & (Shi et al., 2018) & Support surfaces for & Untuk menentukan, & Network Meta- & 1. Cochrane's Risk & Ada bukti kepastian moderat bahwa \\
\hline
\end{tabular}




\begin{tabular}{|c|c|c|c|c|c|c|}
\hline & & $\begin{array}{l}\text { pressure ulcer } \\
\text { prevention: A network } \\
\text { meta-analysis }\end{array}$ & $\begin{array}{l}\text { menggunakan } \\
\text { jaringan meta- } \\
\text { analisis, efek relatif } \\
\text { dari permukaan } \\
\text { dukungan yang } \\
\text { berbeda dalam } \\
\text { mengurangi insiden } \\
\text { tekanan ulkus } \\
\text { dan kenyamanan dan } \\
\text { memberi peringkat } \\
\text { pada permukaan } \\
\text { pendukung ini sesuai } \\
\text { dengan } \\
\text { keefektifannya. }\end{array}$ & analysis & $\begin{array}{l}\text { of Bias tool } \\
\text { 2. } \begin{array}{l}\text { GRADE } \\
\text { principles }\end{array}\end{array}$ & $\begin{array}{l}\text { daya kasur udara aktif dan kasur udara } \\
\text { hibrida bertenaga mungkin mengurangi } \\
\text { insiden tekanan ulkus dibandingkan } \\
\text { dengan permukaan rumah sakit standar. } \\
\text { Jaringan untuk kenyamanan } \\
\text { menyarankan bahwa kasur udara aktif } \\
\text { yang diaktifkan mungkin sedikit kurang } \\
\text { nyaman dibandingkan kasur rumah sakit } \\
\text { standar }\end{array}$ \\
\hline 8 & $\begin{array}{l}\text { (Chiari et al., } \\
\text { 2017) }\end{array}$ & $\begin{array}{l}\text { Predictive Factors for } \\
\text { Pressure Ulcers in an } \\
\text { Older Adult Population } \\
\text { Hospitalized for Hip } \\
\text { Fractures: A Prognostic } \\
\text { Cohort Study }\end{array}$ & $\begin{array}{l}\text { 1.Untuk } \\
\text { mengevaluasi } \\
\text { kejadian tekanan } \\
\text { ulkus dari saat } \\
\text { masuknya pasien } \\
\text { dewasa tua dengan } \\
\text { patah tulang } \\
\text { pinggul proksimal } \\
\text { rapuh } \\
\text { 2.Untuk } \\
\text { mengevaluasi } \\
\text { faktor-faktor } \\
\text { prediktif potensial } \\
\text { yang terkait } \\
\text { dengan perawatan } \\
\text { medis, } \\
\text { keperawatan dan } \\
\text { rehabilitasi pasien, } \\
\text { danuntuk } \\
\text { organisasi }\end{array}$ & $\begin{array}{l}\text { A prospective } \\
\text { multicentric } \\
\text { prognostic cohort } \\
\text { study }\end{array}$ & $\begin{array}{l}\text { 1. Charlson Index } \\
\text { 2.Braden scale } \\
\text { 3. Clinical } \\
\text { evaluation at } \\
\text { presentation } \\
\text { 4.etc }\end{array}$ & $\begin{array}{l}\text { 1. Total Pasien yang mengalami } \\
\text { kejadian ulkus } 22,7 \% \text {. } \\
\text { 2. Faktor risiko: usia> } 80 \text { tahun, lama } \\
\text { penggunaan kateter urin, lama waktu } \\
\text { nyeri, tidak adanya pang tempat tidur } \\
\text { dan tidak adanya penggunaan kasur } \\
\text { anti-dekubitus. Sebaliknya, faktor } \\
\text { protektif adalah adanya pengasuh } \\
\text { setidaknya setengah hari dan jumlah } \\
\text { posisi selama periode pasca operasi }\end{array}$ \\
\hline 9 & $\begin{array}{l}\text { (Zhou et al., } \\
\text { 2014) }\end{array}$ & $\begin{array}{l}\text { Application of the } \\
\text { sheepskin mattress in }\end{array}$ & $\begin{array}{l}\text { 1. Untuk } \\
\text { mengevaluasi }\end{array}$ & An experimental one & $\begin{array}{l}\text { The } m F L E X \\
\text { pressure }\end{array}$ & $\begin{array}{l}\text { 1. intervensi SSM secara signifikan } \\
\text { meningkatkan CA total SHM sebesar }\end{array}$ \\
\hline
\end{tabular}




\begin{tabular}{|c|c|c|c|c|c|c|}
\hline & & $\begin{array}{l}\text { clinical care for pressure } \\
\text { relieving: a quantitative } \\
\text { experimental evaluation }\end{array}$ & $\begin{array}{l}\text { efektivitas SSM } \\
\text { dalam mengurangi } \\
\text { tekanan } \\
\text { 2. Membandingkan } \\
\text { perbedaan antara } \\
\text { SSM dan AM } \\
\end{array}$ & & measuring system & $\begin{array}{l}\text { 395,6 cm2 dan menurunkan PP dan } \\
\text { AP masing-masing sebesar } 8,8 \text { dan } \\
2,0 \mathrm{mmHg} \\
\text { 2. Distribusi tekanan } \mathrm{SSM}+\mathrm{CM} \text { lebih } \\
\text { unggul daripada } \mathrm{AM}+\mathrm{CM}\end{array}$ \\
\hline 10 & $\begin{array}{l}\text { (Moore et al., } \\
\text { 2011) }\end{array}$ & $\begin{array}{l}\text { A randomised controlled } \\
\text { clinical trial of } \\
\text { repositioning, using the } \\
30^{\circ} \text { tilt, for the prevention } \\
\text { of pressure ulcers }\end{array}$ & $\begin{array}{l}\text { Apa efek reposisi } \\
\text { tiga jam di malam } \\
\text { hari, menggunakan } \\
\text { kemiringan } 30^{\circ} \text {, } \\
\text { pada kejadian ulkus } \\
\text { tekanan, pada pasien } \\
\text { yanglebih tua pada } \\
\text { risikopengembangan } \\
\text { ulkus tekanan } \\
\text { dirawat di rumah } \\
\text { sakit dalam } \\
\text { pengaturan } \\
\text { perawatanjangka } \\
\text { panjang? }\end{array}$ & $\begin{array}{l}\text { Cluster-randomised } \\
\text { controlled trial }\end{array}$ & $\begin{array}{l}\text { Braden scale, the } \\
\text { malnutrition } \\
\text { universal screening } \\
\text { tool } \\
(M U S T), \text { the } \\
\text { EPUAP pressure } \\
\text { ulcer classification } \\
\text { system and } \\
\text { the EPUAP } \\
\text { minimum data set. }\end{array}$ & $\begin{array}{l}\text { Reposisi orang yang lebih tua dengan } \\
\text { risiko tekanan ulkus setiap tiga jam pada } \\
\text { malam hari, menggunakan kemiringan } \\
30^{\circ} \text {, mengurangi kejadian ulkus tekanan } \\
\text { dibandingkan dengan perawatan biasa. }\end{array}$ \\
\hline 11 & $\begin{array}{l}\text { (Gillespie, } \\
\text { Chaboyer, } \\
\text { Sykes, O’Brien, } \\
\text { \& Brandis, } \\
\text { 2014) }\end{array}$ & $\begin{array}{l}\text { Development and pilot } \\
\text { testing of a patient- } \\
\text { participatory pressure } \\
\text { ulcer prevention care } \\
\text { bundle. }\end{array}$ & $\begin{array}{l}\text { untuk } \\
\text { mengembangkan dan } \\
\text { mengujicoba PUPCB } \\
\text { yang berpusat pada } \\
\text { pasien untuk pasien } \\
\text { rawat inap }\end{array}$ & Qualitative & $\begin{array}{l}\text { Video singkat, } \\
\text { gabungan brosur / } \\
\text { daftar periksa, dan } \\
\text { poster } \\
\text { dikembangkan } \\
\text { sebagai sumber } \\
\text { pelatihan. Evaluasi } \\
\text { pasien } \\
\text { mengidentifikasi } \\
\text { manfaat dari bundel } \\
\text { perawatan }\end{array}$ & $\begin{array}{l}\text { Format tertulis dari daftar periksa dan } \\
\text { brosur informasi gabungan jauh kurang } \\
\text { berhasil dalam melibatkan pasien } \\
\text { daripada menggunakan format video } \\
\text { dan poster. Maksud dari PUPCB adalah } \\
\text { untuk menciptakan perubahan status quo } \\
\text { dari mana pasien melihat diri mereka } \\
\text { sebagai penerima perawatan pasif ke } \\
\text { mana mereka menjadi aktif terlibat } \\
\text { dalam strategi pencegahan }\end{array}$ \\
\hline
\end{tabular}

